\title{
The Trend of the Reform and Development of the Training of Professional Teachers under the Concept of OBE
}

Jie Zhou*

Faculty of Education, Fujian Normal University, Fouzhou 350000, Fujian Province, China. E-mail: 532410857@qq.com

\begin{abstract}
With the continuous renewal and progress of China's educational concept, the demand for professional talents in various industries is increasing gradually. As colleges and universities undertake the task of talent training, they hope to cultivate various professional talents through professional teaching. Nowadays, with the gradual improvement of education level, the personnel training mechanism of normal universities is more strict. The professional talents of normal colleges and universities are the important resources of schools and training institutions. Therefore, researchers put forward the OBE (Outcomes-based Education) talent training concept. This paper will discuss and study the reform and development of teacher training based on OBE concept, and finally come to a conclusion.
\end{abstract}

Keywords: OBE Concept; Teacher Training; Personnel Training

\section{Introduction}

In fact, the concept of talent training in normal colleges and universities in China is unscientific. Although the students' cultural achievements are relatively ideal, they are lacking in actual comprehensive quality and professional quality. This is a serious problem of personnel training caused by the lack of the educational concept.

For normal colleges and universities, the content and operation of teaching activities are the core of education. There is no doubt that excellent education concept is the main driving force of professional talents training. In order to cultivate professional and comprehensive talents, normal universities need to establish unique educational characteristics. OBE education concept can undertake this task. Educators can fully absorb the educational ideas of OBE to achieve scientific and rigorous training of professional talents.

\section{A brief overview of $\mathrm{OBE}$ education concept}

OBE education concept is an advanced education method which is introduced from abroad to China. People used to call it results-oriented education. Its core is expected learning and knowledge output. Generally speaking, it can train talents through expected learning and knowledge output. Compared with the traditional education concept, the education mode of OBE concept has great advantages in the core values and teaching methods.

The concept of OBE emphasizes the ability of students as the basic orient of teaching. It can focus on the cultivation of students' values by making clear the comprehensive quality of normal school graduates. It has made clear the important means of cultivating talents with students as the center. It can play an important role in the personnel

Copyright (C) 2020 Jie Zhou

doi: $10.18282 /$ le.v9i3.862

This is an open-access article distributed under the terms of the Creative Commons Attribution Non-Commercial License

(http://creativecommons.org/licenses/by-nc/4.0/), which permits unrestricted non-commercial use, distribution, and reproduction in any medium, provided the original work is properly cited. 
training of normal universities.

\section{The great impact of $\mathrm{OBE}$ education concept on the training mode of professional teachers}

The traditional education idea blocks the introduction of OBE education idea. Many educators in normal universities in China are used to the traditional education concept, many of whom can not adapt to the emergence of OBE concept. This phenomenon is quite normal. However, under the education mode of OBE concept, the disadvantages of traditional personnel training methods are very obvious.

Under the traditional concept of personnel training, the school pays more attention to the achievements of culture courses of normal students. The normal school students trained by this concept have high professional scores, but poor comprehensive quality and professional quality. OBE concept can make up for the shortcomings of traditional concept. It centers on the cultivation of students' values. According to a large number of practices and experiments, educators have shown that the emergence of OBE concept can make the fuzzy talent training model of normal universities more clear. This is an undoubtedly huge impact on the traditional talent training model. However, it is worthy to be adapted.

\section{The reform and development of the teaching characteristics of the professional training of teachers in normal colleges under the concept of OBE}

The teaching idea of OBE is oriented. It can make the corresponding teaching plan through the teaching goal by using the reverse method. The establishment of teaching plan is flexible. In the process of talent training, the OBE concept pays more attention to the students' noumenon. Its teaching goal is to help normal students master professional skills and practical skills through the assistance of teachers and students' autonomous learning. In the process of skill learning, students can gradually form their own values. Although everyone's values are different, the orientation of values under the $\mathrm{OBE}$ concept is consistent. Therefore, many normal universities in China need to reflect on themselves and carry out the reform and innovation of talent cultivation.

\subsection{The reform of the talent training mode of normal universities under the concept of OBE}

The traditional training mode of normal universities is archaic, which can only tap the learning potential of students, and neglects the all-round development of students. However, many normal colleges and universities can't abandon the habitual education mode once and for all. Therefore, some normal universities need to innovate the traditional talent training model based on the OBE concept. An important part of the OBE concept can be learned from. Colleges and universities should learn to improve students' autonomous learning ability. Teachers should be able to help students tap their interests and potential. Schools should strive to cultivate students' comprehensive qualities such as group concept, creativity and organizational concept.

\subsection{The development of talent training mode of normal universities under the concept of OBE}

According to a large number of studies, educators found that the talent training mode of OBE education concept is with huge development potential. It not only pays attention to the cultivation of students' professional knowledge, but also help them to find their own areas of expertise and do a good job in their ability positioning. Under the flexible education mode of OBE concept, normal students can make their own learning plans flexibly. Under this kind of education mode, the operation of the training of professional talents in normal schools is effective.

However, the traditional education method in China has been deeply rooted. In this environment, the perfect application of OBE teaching concept is unrealistic for normal universities in China. Therefore, the development of the OBE concept in China is slow in the early stage. Normal schools should first integrate the OBE concept into the model of talent training. With the deepening of the OBE concept, colleges and universities gradually improve the OBE concept to abandon the wrong talent training mode. 


\section{Training strategy of normal talents under the concept of $\mathrm{OBE}$}

The introduction of OBE education concept is not simple, so as the application.

\subsection{Clear training objectives}

There are many kinds of professional talents. Professional teacher talents are not necessarily employed in the future career planning of the education industry. Therefore, colleges and universities should adopt various training strategies, so as to enable students to find their own areas of expertise and their future development direction.

\subsection{Innovation of training mode}

According to the above description, it is clear that the training mode of normal talents with OBE concept is totally different from the traditional one. Therefore, to innovate training mode, normal universities need to adopt excellent education ideas and professional teachers. The gradual improvement of education mode can slowly adapt to the training mode under the concept of OBE.

\subsection{Improvement of evaluation system}

In normal colleges and universities, the traditional evaluation model mainly focuses on students' cultural achievements rather than their comprehensive quality. After adopting the OBE concept, the evaluation mode of colleges and universities should also be improved. It should be noted that students' cultural achievements are very important. However, their comprehensive quality is the most important.

\section{Conclusion}

The professional talents of normal schools are the important motive force to advance the education of China. The introduction of OBE concept can help normal universities to train talents. Although the OBE concept will greatly impact the traditional education concept, it is still necessary to make changes. There will always be a return.

\section{Acknowledgments}

Projects: The key project of the "13th Five-Year Plan" of education science in Fujian Province in 2018, "Research on the reform of the training program of engineering education professionals under OBE concept" (No.: 2018CG02876) and the research results of the project on Fujian Normal University's undergraduate teaching reform in 2019, "Reform and exploration of the construction of the teaching management service system of the second class gold course" (No.: I2019020-01).

\section{References}

1. $\mathrm{Xu} \mathrm{J}$. The training mode of accounting talents under the trend of artificial Intelligence development. Shanxi Science and Technology 2018; 33(2): 129-131.

2. Li L. Research on reform of digital and creative talents training under perspective of OBE concept_- The case of higher education institution in Shenzhen region. Vocational and Technical Education 2018; 39(11): 40-44.

3. Lin $\mathrm{J}, \mathrm{Wu} \mathrm{J}$. The strategies for educational reform of advertising in colleges and universities under the development of new media. 5th International Conference on Education, Language, Art and Inter-cultural Communication; 2018 Oct 10.

4. Zeng X, Wu Q, Qiu J. Construction of practical teaching system of "Smartphone UI Design" in higher vocational colleges under the concept of CDIO. 3rd International Conference on Economics, Management Engineering and Education Technology; 2019 May.

5. Mao X, Luo Y, Lu Z, et al. Study on the reform of talent training mode of vehicle engineering in application-oriented undergraduate universities based on OBE concept taking the vehicle engineering majors in Nantong Institute of Technology as an example (in Chinese). Auto Time 2019; (4): 62-63.

6. Strauss RS, Knight J. Influence of the home environment on the development of obesity in children. Pediatrics 
1999; 103(6): 85. doi: 10.1542/peds.103.6.e85. 